\title{
Reconstitution of Mutant V2 Vasopressin Receptors by Adenovirus-mediated Gene Transfer

\author{
Molecular Basis and Clinical Implication
}

\author{
Torsten Schöneberg, ${ }^{\star}$ Volker Sandig, ${ }^{\ddagger}$ Jürgen Wess, ${ }^{\S}$ Thomas Gudermann, ${ }^{*}$ and Günter Schultz* \\ *Institut für Pharmakologie, Fachbereich Humanmedizin, Freie Universität Berlin, D-14195 Berlin, Germany; ${ }^{\ddagger}$ Max-Delbrück-Zentrum \\ für Molekulare Medizin Berlin-Buch, D-13122 Berlin, Germany; and ${ }^{\S}$ Laboratory of Bioorganic Chemistry, National Institute of Diabetes \\ and Digestive and Kidney Diseases, National Institutes of Health, Bethesda, Maryland 20892
}

\begin{abstract}
Recent studies with transfected COS-7 cells have shown that functionally inactive mutant $\mathrm{V} 2$ vasopressin receptors (occurring in patients with nephrogenic diabetes insipidus) can be functionally rescued by coexpression of a carboxyterminal V2 receptor fragment (V2-tail) spanning the region where various mutations occur [Schöneberg, T., J. Yun, D. Wenkert, and J. Wess. 1996. EMBO (Eur. Mol. Biol. Organ.) J. 15:1283-1291]. In this study, we set out to characterize the underlying molecular mechanism. Using a coimmunoprecipitation strategy and a newly developed sandwich ELISA system, a direct and highly specific interaction between the mutant $\mathrm{V} 2$ vasopressin receptor proteins and the V2-tail polypeptide was demonstrated. To study the potential therapeutic usefulness of these findings, Chinese hamster ovary (CHO) cell lines stably expressing low levels of functionally inactive mutant V2 vasopressin receptors were created and infected with a recombinant adenovirus carrying the V2-tail gene fragment. After adenovirus infection, vasopressin gained the ability to stimulate cAMP formation with high potency and efficacy in all CHO cell clones studied. Moreover, adenovirus-mediated gene transfer also proved to be a highly efficient method for achieving expression of the V2-tail fragment (as well as the wild-type V2 receptor) in Madin-Darby canine kidney tubular cells. Taken together, these studies clarify the molecular mechanisms by which receptor fragments can restore function of mutationally inactivated $G$ protein-coupled receptors and suggest that adenovirus-mediated expression of receptor fragments may lead to novel strategies for the treatment of a variety of human diseases. (J. Clin. Invest. 1997. 100: 1547-1556.) Key words: nephrogenic diabetes insipidus • vasopressin receptor $\cdot$ gene therapy $\bullet$ receptor mutagenesis • receptor folding
\end{abstract}

\footnotetext{
Address correspondence to Dr. Torsten Schöneberg, Institut für Pharmakologie, Freie Universität Berlin, Thielallee 69-73, D-14195 Berlin, Germany. Phone: 49-30-838-5223; FAX: 49-30-831-5954; E-mail: schoberg@zedat.fu-berlin.de

Received for publication 30 January 1997 and accepted in revised form 3 July 1997.
}

J. Clin. Invest.

(C) The American Society for Clinical Investigation, Inc. 0021-9738/97/09/1547/10 \$2.00

Volume 100, Number 6, September 1997, 1547-1556

http://www.jci.org

\section{Introduction}

It has become clear during the past decade that $\mathrm{G}$ proteincoupled receptors (GPCRs) ${ }^{1}$ form one of the largest protein families found in nature (1). Recently, it has been demonstrated that mutations in distinct GPCRs are responsible for several hereditary and acquired diseases such as retinitis pigmentosa (2), familial male precocious puberty (3), hyperthyroidism (4), or X-linked nephrogenic diabetes insipidus (NDI) (5). Several dozens of different mutations have been identified in the V2 vasopressin receptor gene of NDI patients (6), making the kidneys insensitive to the antidiuretic actions of the hormone arginine vasopressin (AVP). The vast majority of these mutations results in single amino acid substitutions (missense mutations) or receptor truncations caused by nonsense or frameshift mutations (7).

Based on findings that GPCRs are composed of multiple folding units $(8,9)$, we demonstrated recently in transiently transfected COS-7 cells that mutant V2 vasopressin receptors containing clinically relevant mutations in the carboxy-terminal third of the receptor protein can be functionally rescued by coexpression of a nonmutated carboxy-terminal V2 receptor fragment (V2-tail) (10). To test the hypothesis that this phenomenon is due to a direct interaction between the two polypeptides, we used here a coimmunoprecipitation and a newly developed sandwich ELISA strategy. Thus, we could show that the V2-tail can associate directly with a truncated V2 receptor (E242stop) but not with other classes of GPCRs containing similar mutations.

The second major goal of this study was to test the potential therapeutic usefulness of this coexpression strategy. Toward this aim, Chinese hamster ovary (CHO) cell lines expressing low levels of functionally inactive mutant V2 receptors which more closely mimic the physiological situation were infected with a recombinant adenovirus carrying the V2-tail gene fragment. Adenoviral vectors can deliver recombinant genes efficiently to a great number of diverse cell types, including mitotically quiescent cells, and are therefore considered promising candidates for a number of potential human gene therapy applications $(11,12)$. Whereas noninfected $\mathrm{CHO}$ cell lines (expressing mutant V2 receptors) did not show a functional response upon addition of AVP, infection of the individual $\mathrm{CHO}$ cell clones with recombinant V2-tail adenovirus enabled AVP to induce a pronounced cAMP response. Furthermore, we showed that recombinant adenoviruses can be

\footnotetext{
1. Abbreviations used in this paper: AVP, arginine vasopressin; CCK, cholecystokinin; $\mathrm{CHO}$, Chinese hamster ovary; GnRH, gonadotropinreleasing hormone; GPCR, G protein-coupled receptor; HA, hemagglutinin; LH, luteinizing hormone; MDCK, Madin-Darby canine kidney; NDI, nephrogenic diabetes insipidus; Ox, oxytocin; RT, reverse transcription; V2-tail, carboxy-terminal V2 receptor fragment.
} 

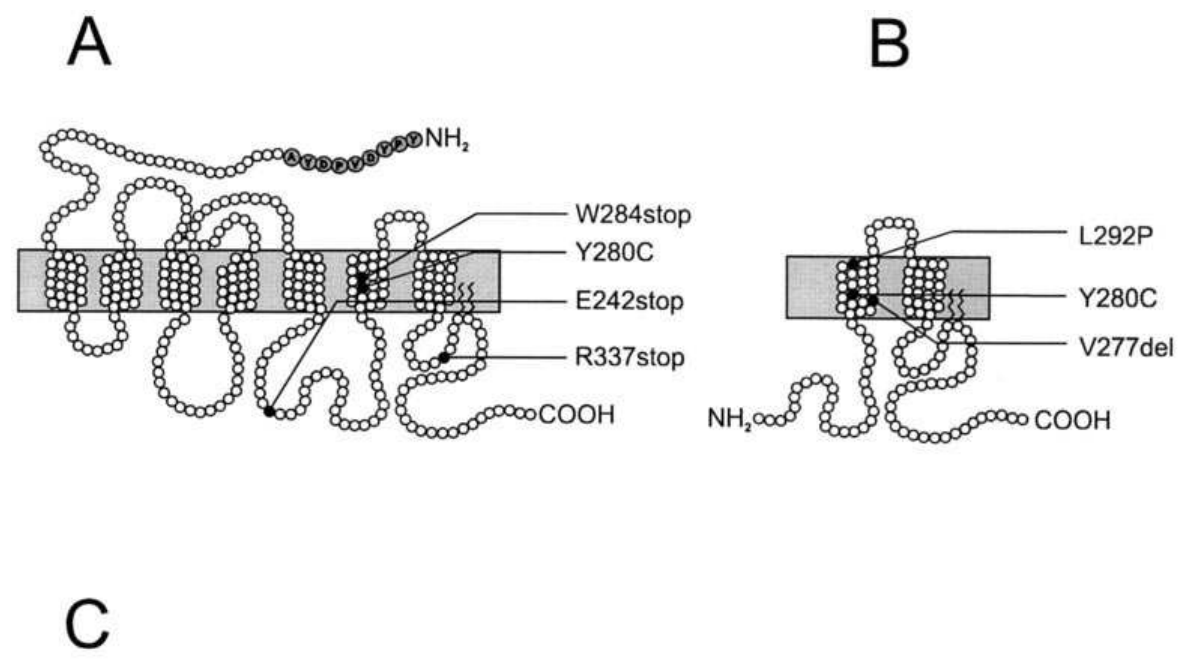

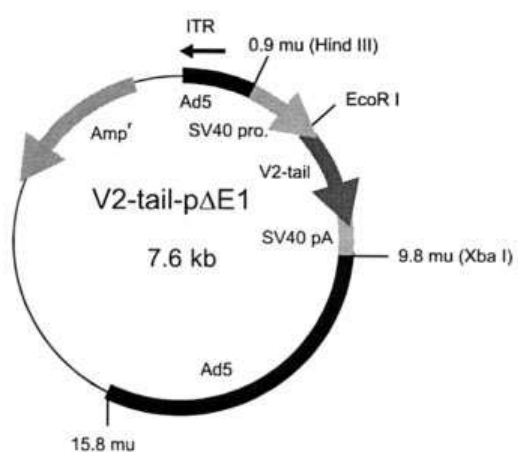

co-transfection of 293 cells intracellular recombination

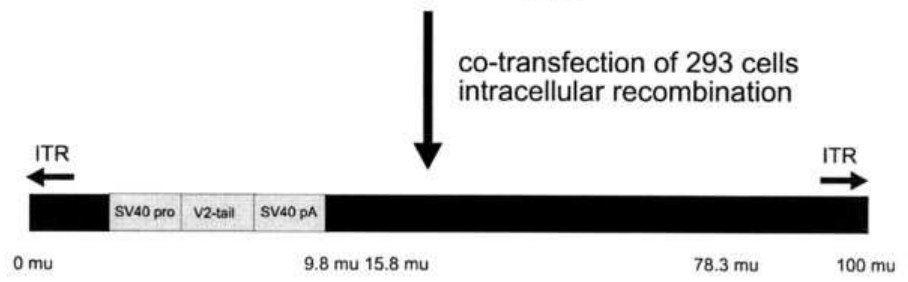

Ad-V2-tail

Figure 1. V2 vasopressin receptor constructs used in this study, and construction of recombinant adenoviruses. (A) Truncated (E242stop, W284stop, and Y280CR337stop; filled black circles) and fulllength wild-type and mutated $\mathrm{V} 2$ receptors (Y280C; filled black circles) were tagged with a 9-amino acid HA-epitope (filled gray circles). (B) Mutant V2-tail constructs (point mutations Y280C, L292P and deletion V277del; filled black circles) were created by subcloning mutated fragments from full-length $\mathrm{V} 2$ receptor mutants into the V2-tail constructs. $(C)$ Expression cassettes of V2-tail and wild-type V2 receptor (not shown) were introduced into the polylinker site of $\mathrm{p} \Delta \mathrm{E} 1 \mathrm{sp} 1 \mathrm{~B}$. pJM17 contains the adenovirus type 5 sequence. Homologous recombination between the two plasmids (after cotransfection into 293 cells) led to the formation of a replicationdeficient recombinant adenovirus containing the V2-tail (Ad-V2-tail) or wild-type $\mathrm{V} 2$ receptor (Ad-V2) DNA (not shown). $A m p^{\mathrm{r}}$, ampicillin resistance gene. ITR, inverted terminal repeat. $m u$, map units. ori, origin. SV40 pro, SV40 early region promoter. $S V 40 \mathrm{pA}, \mathrm{SV} 40$ polyadenylation signal. used to achieve efficient expression of the V2-tail fragment and of the wild-type V2 receptor not only in fibroblasts but also in Madin-Darby canine kidney (MDCK) tubular cells as well.

Taken together, our data suggest that adenovirus-mediated expression of receptor fragments results in cell-specific molecular correction of functional receptor defects, and may lead to novel strategies in the treatment of diseases caused by inactivating mutations of GPCRs.

\section{Methods}

Construction of mutant V2 vasopressin receptor genes and recombinant adenoviral vectors. Mutant V2 receptors (Fig. 1, $A$ and $B$ ) were created by standard PCR mutagenesis techniques (13), using the human V2 vasopressin receptor expression plasmid V2-pcD-PS (10) as a template. In the case of truncated receptors, the coding sequence downstream of the newly introduced stop codon was partially removed (deletion of $232 \mathrm{bp}$ in E242stop and $106 \mathrm{bp}$ in W284stop). The wild-type human gonadotropin-releasing hormone $(\mathrm{GnRH})$ receptor (recloned from the human pituitary by R. Grosse and T. Gudermann), rat vasopressin V1a receptor (14), human oxytocin (Ox) re- ceptor (15), human cholecystokinin type $\mathrm{A}\left(\mathrm{CCK}_{\mathrm{A}}\right)$ receptor (16), and mouse luteinizing hormone (LH) receptor (17) were subcloned into pcD-PS. In addition, the wild-type and various mutant V2 vasopressin receptors, $\mathrm{GnRH}$ receptor, $\mathrm{CCK}_{\mathrm{A}}$ receptor, and rat $\mathrm{m} 3$ muscarinic receptor (9), were tagged with an amino-terminal 9-amino acid sequence (YPYDVPDYA) (18) derived from the influenza virus hemagglutinin protein (HA-tag). The identity of the various constructs and the correctness of all PCR-derived sequences were confirmed by restriction analysis and dideoxy sequencing (19).

Recombinant (E1-deficient) adenoviruses (serotype 5) carrying the wild-type V2 receptor and the V2-tail polypeptide (Fig. 1 C) were generated as follows. The coding sequences of the HA-tagged wildtype $\mathrm{V} 2$ receptor and the V2-tail polypeptide, including the non-tissue-specific SV40 early region promoter and SV40 polyadenylation signal (taken from pcD-PS vector), were inserted into the pdE1sp1B vector (20) via the EcoRI site present in the polylinker sequence. The two resulting plasmids were then cotransfected with the pJM17 plasmid (21) into subconfluent HEK 293 cells using a modified calcium phosphate coprecipitation method (22). After plaque isolation, recombinant viruses, referred to as Ad-V2 and Ad-V2-tail, were amplified, and individual virus stocks were analyzed by PCR and restriction analysis.

For preparation of large purified virus stocks, HEK 293 cells were infected $(\sim 5$ pfu/cell $)$ and harvested after cytopathic effects became 
visible (48 h). Cells were lysed in PBS containing 0.2\% NP-40. After removing cell debris, the virus suspension was subjected to two $\mathrm{CsCl}$ step gradient centrifugations as described (23). $\mathrm{CsCl}$ was removed by gel filtration through Sephadex G25 columns (Pharmacia Diagnostics $\mathrm{AB}$, Uppsala, Sweden), and aliquots were stored at $-70^{\circ} \mathrm{C}$ in storage buffer containing $150 \mathrm{mM} \mathrm{NaCl}, 3 \mathrm{mM} \mathrm{KCl}, 1 \mathrm{mM} \mathrm{MgCl}_{2}, 10 \mathrm{mM}$ Tris- $\mathrm{HCl}(\mathrm{pH} 7.4)$, and $10 \%$ glycerol. Titers were determined by plaque assay in HEK 293 cells.

Cell culture and gene transfer. Cells were grown in DMEM (COS-7 and MDCK cells) and Ham's F12 medium (CHO-K1 cells), supplemented with $10 \%$ FBS. For transient transfections of COS-7 cells, a DEAE-dextran method was used (24). In brief, $4 \mu \mathrm{g}$ plasmid DNA per 10-cm dish was transfected. To establish CHO-K1 cell lines stably expressing wild-type or mutant $\mathrm{V} 2$ receptors, receptor constructs were cotransfected with pcDNAneo (Invitrogen Corp., Leek, The Netherlands) using lipofectamin (Life Technologies, Inc., Eggenstein, Germany) and a V2 receptor construct to pcDNAneo ratio of 20:1 (4 $\mu \mathrm{g}$ total amount of plasmid DNA). Single colonies resistant to the antibiotic G418 (700 $\mu \mathrm{g} / \mathrm{ml}$; Life Technologies, Inc.) were isolated and maintained in Ham's F12 medium supplemented with G418 $(400 \mu \mathrm{g} / \mathrm{ml})$. Adenoviral infections were carried out in petri dishes containing cell monolayers at $90 \%$ confluency. The appropriate virus dilution (in PBS containing $2 \mathrm{mM} \mathrm{MgCl}$ ) was dripped onto the cells, and the plates were incubated at room temperature for $1 \mathrm{~h}$. The viruscontaining medium was aspirated, and cells were cultured for $72 \mathrm{~h}$ until use. To estimate infection efficiencies, $\mathrm{COS}-7, \mathrm{CHO}$, and MDCK cells were infected with various concentrations of a recombinant adenovirus carrying the $\beta$-galactosidase gene under the control of Rous sarcoma virus promoter (25), as described above. $3 \mathrm{~d}$ after infection, cells were fixed in PBS containing $0.05 \%$ glutardialdehyde, and $\beta$-galactosidase activity was detected by staining cells with $3 \mathrm{mM} \mathrm{K}_{3} \mathrm{Fe}(\mathrm{CN})_{6} / 3$ $\mathrm{mM} \mathrm{K}{ }_{4} \mathrm{Fe}(\mathrm{CN})_{6} / 2 \mathrm{mM} \mathrm{MgCl} / 5$-bromo-4-chloro-3-indolyl $\beta$-D-galactoside $(0.5 \mathrm{mg} / \mathrm{ml})$ in Hepes buffer $(\mathrm{pH} 7.4)$. The percentage of blue cells was determined from random fields, and at least 800 cells were counted per plate.

Immunoprecipitation. COS-7 cells were transfected with various V2 receptor constructs as described above. About $18 \mathrm{~h}$ later, cells were split into 6 -well plates $\left(5 \times 10^{5}\right.$ cells/well). On the following day, transfected cells were incubated with $\left.{ }^{35} \mathrm{~S}\right]$ methionine $(0.5 \mathrm{mCi} / \mathrm{ml}$ in culture medium; Dupont-NEN, Brussels, Belgium) for an additional $18 \mathrm{~h}$. Cells were then washed twice with PBS and treated with $120 \mu \mathrm{l}$ lysis buffer (10 mM Tris- $\mathrm{HCl}, \mathrm{pH} 7.4,150 \mathrm{mM} \mathrm{NaCl}, 1 \mathrm{mM}$ DTT, $1 \mathrm{mM}$ EDTA, $1 \%$ desoxycholate, $1 \%$ NP-40, $0.2 \mathrm{mM}$ PMSF, $10 \mu \mathrm{g} / \mathrm{ml}$ aprotinin). After vigorous vortexing, followed by removal of cell debris by centrifugation, $20 \mu \mathrm{g} / \mathrm{ml}$ of the anti-V2 receptor antibody was added to the supernatants containing solubilized receptor protein. After incubation of samples at $4^{\circ} \mathrm{C}$ for $2 \mathrm{~h}$ in constant rotation, $60 \mu \mathrm{l}$ of $10 \%$ (wt/vol) protein A-Sepharose beads (Sigma Chemical Co., Deisenhofen, Germany) was added, and samples were incubated overnight at $4^{\circ} \mathrm{C}$. Sepharose beads were pelleted $(12,000 \mathrm{~g}, 3 \mathrm{~min})$ and washed twice with $1 \mathrm{ml}$ washing buffer A $(600 \mathrm{mM} \mathrm{NaCl}, 50 \mathrm{mM}$ Tris- $\mathrm{HCl}$, $\mathrm{pH} 7.4,0.1 \%$ Triton X-100, 1\% NP-40) and twice with $1 \mathrm{ml}$ washing buffer B (300 mM NaCl, $10 \mathrm{mM}$ EDTA, $100 \mathrm{mM}$ Tris-HCl, pH 7.4). Pellets were then boiled with $40 \mu \mathrm{l}$ SDS sample buffer, and SDSPAGE $(12.5 \%)$ was performed. Precipitated ${ }^{35} \mathrm{~S}$-labeled membrane proteins were visualized by autoradiography of the dried gels with X-OMAT AR-5 film (Eastman Kodak Co., Rochester, NY).

ELISAs. To estimate cell surface expression of receptors carrying an amino-terminal HA-tag, we developed an indirect cellular ELISA (9). Briefly, transfected COS-7 cells were seeded into 96-well plates, fixed without disrupting the cell membrane, and incubated with an anti-HA mAb (12CA5; Boehringer Mannheim, Mannheim, Germany). Bound anti-HA antibody was then detected with the help of a peroxidase-labeled anti-mouse IgG antibody (Sigma Chemical Co.).

To further assess the association between amino- and carboxyterminal receptor fragments, the following sandwich ELISA was developed. $3 \mathrm{~d}$ after transfection, COS-7 cells were harvested, and cell pellets were resuspended in lysis buffer (see above). Cell debris was removed by centrifugation, and supernatants were used for ELISA measurements. Microtiter plates were coated with a polyclonal rabbit antibody directed against a peptide corresponding to the carboxy-terminal 29 amino acids of the human V2 vasopressin receptor $(5 \mu \mathrm{g} / \mathrm{ml}$ in PBS; kindly provided by Dr. Paul Goldsmith, National Institutes of Health, Bethesda, MD). After incubation for $16 \mathrm{~h}$ at $4^{\circ} \mathrm{C}$, plates were blocked with $10 \%$ FBS in PBS. Cell lysates were then applied and incubated for $2 \mathrm{~h}$ at $37^{\circ} \mathrm{C}$. Plates were washed three times with PBS containing $0.05 \%$ Triton X-100 (PBS-T). The anti-HA mAb (12CA5; $1 \mu \mathrm{g} / \mathrm{ml}$ PBS-T) was then added, and plates were incubated for $2 \mathrm{~h}$ at $37^{\circ} \mathrm{C}$. Plates were washed with PBS-T and incubated with a 1:3,000 dilution of a peroxidase-conjugated anti-mouse IgG antibody for $1 \mathrm{~h}$ at $37^{\circ} \mathrm{C}$. After removal of excess unbound antibody, $\mathrm{H}_{2} \mathrm{O}_{2}$ and $o$-phenylenediamine $(2.5 \mathrm{mM}$ each in $0.1 \mathrm{M}$ phosphate-citrate buffer, $\mathrm{pH}$ 5.0) were added to serve as substrate and chromogen, respectively. After $15 \mathrm{~min}$, the enzyme reaction (carried out at room temperature) was stopped by the addition of $1 \mathrm{M} \mathrm{H}_{2} \mathrm{SO}_{4}$ containing $0.05 \mathrm{M} \mathrm{Na}_{2} \mathrm{SO}_{3}$, and color development was measured bichromatically at 492 and $620 \mathrm{~nm}$ using an ELISA reader (Titertek Multiskan MCC/340; Labsystems Inc., Helsinki, Finland).

Functional assays. Inositol phosphate and cAMP measurements were performed as described previously $(9,10)$. For radioligand-binding studies, cells were harvested $72 \mathrm{~h}$ after transfection or infection, and binding assays were performed using membrane homogenates. Incubations were carried out for $1 \mathrm{~h}$ at $22^{\circ} \mathrm{C}$ in a $0.25-\mathrm{ml}$ volume, with $16 \mathrm{nM}\left[{ }^{3} \mathrm{H}\right]$ AVP $(64 \mathrm{Ci} / \mathrm{mmol}$; Dupont-NEN). Nonspecific binding was defined as binding in the presence of $5 \mu \mathrm{M}$ AVP. The protein content of samples was determined by the method of Bradford (26). Binding data were analyzed by a nonlinear least squares curve-fitting procedure using the computer program LIGAND (27).

$m R N A$ preparation and reverse transcription followed by $P C R$ (RT-PCR). G418-resistant CHO cell clones were screened for (mutant) V2 receptor mRNA expression by RT-PCR. Cells $\left(10^{6}\right)$ were washed twice with PBS, and mRNA was prepared using the Oligote ${ }^{\circledR}$ direct mRNA kit (QIAGEN Inc., Hilden, Germany). Firststrand cDNA was synthesized by reverse transcriptase (Stratagene Inc., Heidelberg, Germany) using an oligo-dT primer as recommended. To estimate cDNA copy numbers, a competitive PCR was performed according to a method described by Siebert and Larrick (28). Thus, cDNA and an internal DNA standard (genomic V2 vasopressin receptor in pcD-PS) were coamplified in the PCR experiments. The resultant PCR products were electrophoresed, and ethidium bromide-stained DNA bands were visualized under ultraviolet (UV) light.

Immunofluorescence studies. Immunofluorescence studies were carried out to examine the subcellular distribution of wild-type and mutant vasopressin V2 receptors. $1 \mathrm{~d}$ after infection of COS-7 or MDCK cells (100 pfu/cell), cells were transferred into 6-well plates containing sterilized glass coverslips. Approximately $48 \mathrm{~h}$ later, cells were fixed and probed with a rabbit polyclonal antibody directed against the carboxy terminus of the human V2 receptor as described previously (10). Fluorescence images were obtained with a confocal laser scanning microscope (model LCM 410; Carl Zeiss, Inc., Thornwood, NY).

\section{Results}

Mechanism of functional rescue. To test the hypothesis that the ability of the V2-tail polypeptide to restore function to selected mutant V2 vasopressin receptors is due to a direct association between the two polypeptides, a coimmunoprecipitation strategy was used. COS-7 cells were cotransfected with plasmids coding for V2-tail and E242stop, labeled with $\left[{ }^{35} \mathrm{~S}\right]$ methionine, and immunoprecipitated proteins were separated by SDS-PAGE. As shown in Fig. 2, the wild-type V2 receptor migrated as a broad band ranging from 38 to $43 \mathrm{kD}$, 


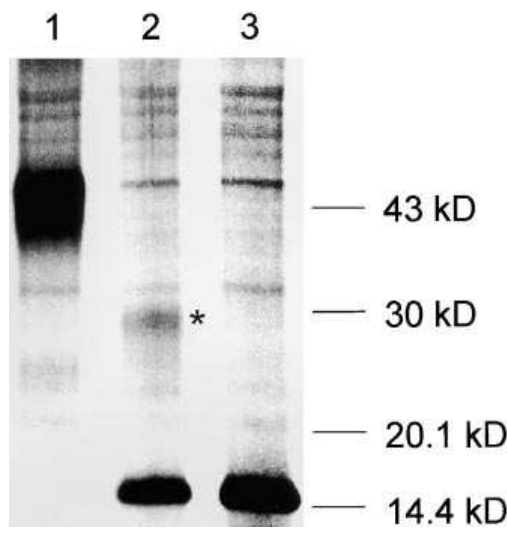

Figure 2. Immunoprecipitation of V2 receptor constructs. COS-7 cells were transfected with plasmids ( $4 \mu \mathrm{g}$ total DNA/dish) coding for the wild-type V2 receptor (lane 1 ), E242stop and V2-tail (DNA ratio 1:1; lane 2), or V2-tail (lane 3 ) and incubated with $\left[{ }^{35} \mathrm{~S}\right] \mathrm{me}$ thionine for $18 \mathrm{~h}$. Crude cell membranes were prepared and lysed. Immunoprecipitation (us-

ing an antibody directed against the carboxy-terminal portion of the V2 receptor) and SDS electrophoresis were performed as described in Methods. *Coprecipitated V2 receptor fragment, E242stop. One representative experiment out of three is shown.

whereas the V2-tail polypeptide was detectable as a $14-\mathrm{kD}$ band. When the V2-tail fragment was coexpressed with the E242stop truncation mutant, an additional band could be detected at $\sim 29 \mathrm{kD}$. No specific bands were observed when the E242stop construct was transfected alone or when COS-7 cells expressing the wild-type $\mathrm{V} 2$ receptor or $\mathrm{V} 2$-tail were incubated with a nonspecific antibody (rabbit anti- $\mathrm{CCK}_{\mathrm{A}}$ receptor antibody, data not shown).

To further characterize the interaction of the V2-tail polypeptide with the mutant V2 receptors, a novel sandwich ELISA system was developed (Fig. $3 A$ ). COS-7 cells transfected with wild-type V2 receptor DNA ( $4 \mu \mathrm{g} /$ dish) showed high receptor expression levels of $\sim 500 \mathrm{fmol} / \mathrm{mg}$ protein, and transfected wild-type receptor DNA (4-100 ng plasmid DNA) as well as membrane lysates (1:10) had to be diluted for sandwich ELISA to correlate OD readings directly with $\mathrm{B}_{\max }$ values (Fig. 3 B). For control purposes, cell lysates were also prepared from COS-7 cells transfected with $\mathrm{CCK}_{\mathrm{A}}, \mathrm{GnRH}$, and $\mathrm{m} 3$ muscarinic receptor constructs containing an amino-terminal HA-tag. The epitope tags did not interfere with the proper expression and function of these receptors (data not shown).
In all three cases, OD values were indistinguishable from background values determined with lysis buffer alone (data not shown). Similarly, membrane lysates prepared from COS-7 cells transfected with E242stop or V2-tail alone or mixed after solubilization did not result in OD readings that were significantly higher than background, even when the sandwich ELISA was performed with undiluted membrane lysates (Table I). However, a six- to sevenfold increase in OD readings (compared to background values) was obtained when membrane lysates prepared from cells cotransfected with E242stop and V2-tail were assayed by sandwich ELISA, strongly suggesting that the two polypeptides are directly associated with each other. This interaction was no longer observed when membrane lysates were heated to $80^{\circ} \mathrm{C}$ for $10 \mathrm{~min}$ (Table I). Similar results were obtained by adding SDS (1\% wt/vol) to the membrane lysates, whereas SDS treatment of membrane lysates from wild-type V2 receptor transfected cells had little influence on OD readings in sandwich ELISA (data not shown). Introduction of the Y280C point mutation (which functionally inactivates the wild-type V2 receptor) into the V2tail polypeptide led to a mutant $\mathrm{V} 2$ receptor fragment (V2Y280C-tail) that retained the ability to associate efficiently with the E242stop mutant receptor (see Table I). Similar results were obtained when various other mutations known to functionally inactivate the wild-type V2 receptor (e.g., L292P or V277del) were introduced into the V2-tail fragment (data not shown). To further characterize the underlying mechanism leading to functional reconstitution of nontruncated receptor mutants, e.g., Y280C (10), the interaction of the V2-tail fragment with Y280C was studied in the sandwich ELISA. Therefore, the carboxy-terminal antibody recognition site was removed from a receptor construct, referred to as Y280CR337stop, to allow interaction studies in the ELISA. Membrane lysates from COS-7 cells cotransfected with Y280CR337stop and V2-tail plasmids showed increased OD values in the test (see Table I). In another set of control experiments, the V2-tail polypeptide was coexpressed with HA-tagged wildtype $\mathrm{m} 3$ muscarinic receptor, and HA-tagged mutant GnRH or $\mathrm{m} 3$ muscarinic receptors that were truncated in their third intracellular loops in a fashion similar to the E242stop V2 mutant receptor. As expected, membrane lysates prepared from
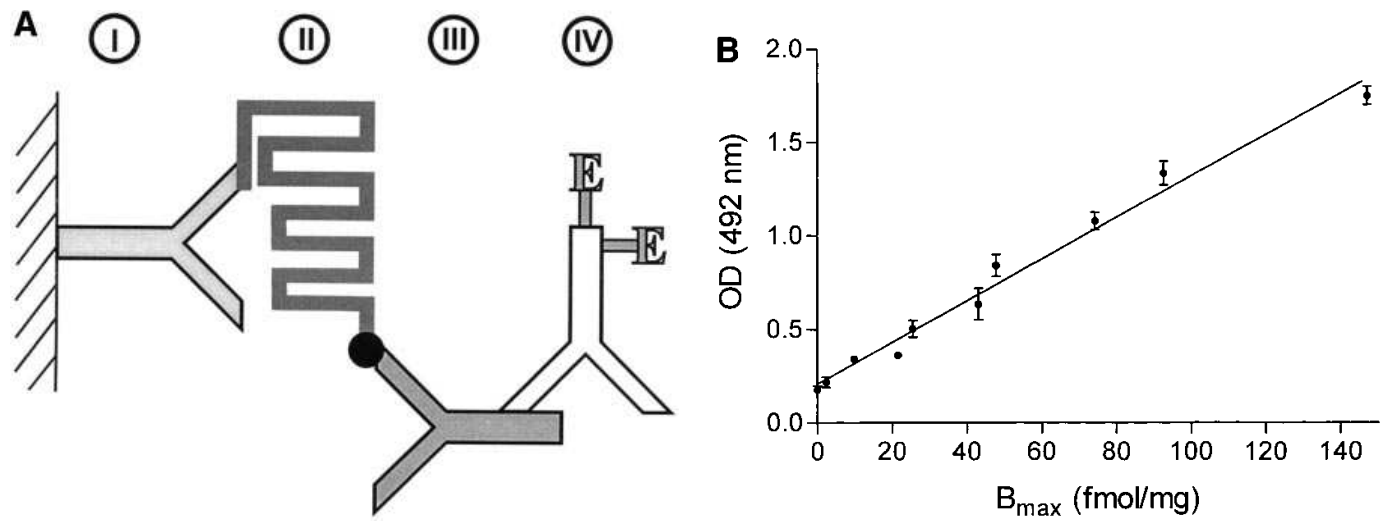

Figure 3. Relationship between V2 vasopressin receptor density and extinction determined by sandwich ELISA. $(A)$ Microtiter plates were coated with a polyclonal antibody directed against the carboxy-terminal portion of the V2 receptor $(I)$. Solubilized HA-tagged receptor proteins $(I I)$ were caught by the carboxy-terminal antibody and detected using an

HA-specific mAb (III), followed by incubation with a peroxidase-linked anti-mouse antibody $(I V)$. $(B)$ COS-7 cells were transfected with increasing amounts of V2 (wt) receptor DNA (4-100 ng). For sandwich ELISA measurements, cells were harvested $72 \mathrm{~h}$ after transfection, and crude cell membranes were prepared. Membranes or lysates were used for $\left[{ }^{3} \mathrm{H}\right]$ AVP saturation-binding assays or sandwich ELISA. ELISA and radioligand-binding studies were carried out as described in Methods. Data are given as means \pm SEM of two independent experiments, each carried out in duplicate (binding assay) or triplicate (ELISA). 
Table I. Fragment Association Determined by Sandwich ELISA

\begin{tabular}{lc}
\hline \multicolumn{1}{c}{ Construct } & $\mathrm{OD}_{492 \mathrm{~nm}}$ \\
\hline Wild-type V2/vector (1:2) & $1.275 \pm 0.010$ \\
E242stop & $0.154 \pm 0.003$ \\
V2-tail & $0.141 \pm 0.002$ \\
E242stop + V2-tail (mixed after solubilization) & $0.143 \pm 0.002$ \\
E242stop + V2-tail (cotransfected) & $1.006 \pm 0.015$ \\
E242stop + V2-tail (cotransfected + heating) & $0.089 \pm 0.001$ \\
E242stop + V2-Y280C-tail (cotransfected) & $0.978 \pm 0.036$ \\
Y280C-R337stop + V2-tail (cotransfected) & $0.878 \pm 0.047$ \\
Wild-type m3 + V2-tail (cotransfected) & $0.142 \pm 0.005$ \\
m3-S318stop + V2-tail (cotransfected) & $0.137 \pm 0.001$ \\
GnRH-L285stop + V2-tail (cotransfected) & $0.148 \pm 0.003$ \\
\end{tabular}

Membrane lysates prepared from COS-7 cells transfected with E242stop or V2-tail alone ( $4 \mu \mathrm{g}$ plasmid DNA/dish) or mixed after solubilization were tested in a sandwich ELISA (OD $492 \mathrm{~nm}$ ). To detect fragment association, the truncated V2 receptor (E242stop) was cotransfected with V2-tail or V2-Y280C-tail. Additionally, lysates of cotransfected E242stop/V2-tail (DNA ratio 1:1; $4 \mu \mathrm{g}$ total plasmid DNA/dish) were incubated at $80^{\circ} \mathrm{C}$ for $10 \mathrm{~min}$ and then tested in ELISA. HA-tagged $\mathrm{m} 3$ muscarinic receptor or truncated GnRH (GnRH-L285stop) or m3 muscarinic (m3-S318stop) receptors were cotransfected with V2-tail to evaluate the specificity of fragment association. Data are given as means \pm SEM of two independent experiments, each performed in triplicate.

these cells did not give specific OD readings in the sandwich ELISA (see Table I), demonstrating that the V2-tail fragment interacted with the E242stop V2 mutant receptor with high specificity.

Coexpression of the V2-tail polypeptide with other GPCRs. Next, we wanted to show that overexpression of the V2-tail polypeptide does not interfere with the function of other
GPCRs. Toward this goal, COS-7 cells were cotransfected with plasmids coding for the V2-tail fragment and several other GPCRs such as the V1a vasopressin, Ox, GnRH, $\mathrm{CCK}_{\mathrm{A}}$, or LH receptors.

As shown in Table II, the coexpressed V2-tail polypeptide had no significant effect on the potency and efficacy of second messenger responses mediated by the different receptors, suggesting that even high levels of the V2-tail polypeptide (as observed in transiently transfected COS-7 cells) did not interfere with the function of other GPCRs.

Characterization of $\mathrm{CHO}$ cell lines stably expressing wildtype and mutant $V 2$ receptors. To establish a cellular model system that would closely mimic the physiological situation of receptor expression levels, stable $\mathrm{CHO}$ cell lines were created by cotransfection of the wild-type or various mutant V2 vasopressin receptors (E242stop, Y280C, and W284stop) and pcDNAneo. Several G418-resistant cell lines were screened for receptor expression by radioligand-binding, functional, or immunological techniques. Cell lines transfected with the wild-type V2 receptor gene were functionally screened by measuring AVPinduced increases in intracellular cAMP levels. Two cell clones, V2-1 and V2-2, that differed in the magnitude of AVP-induced cAMP responses (Table III) were maintained for further experiments. $\left[{ }^{3} \mathrm{H}\right] \mathrm{AVP}$ radioligand-binding studies showed that the CHO-V2-1 cell clone expressed $\sim 21$ fmol receptor protein per milligram of membrane protein, whereas the $\mathrm{CHO}$ V2-2 cell clone did not show any specific $\left[{ }^{3} \mathrm{H}\right]$ AVP binding activity, apparently due to a very low level of receptor expression (see Table III).

Since the mutant V2 receptors used in this study were unable to bind radioligand or to induce a second messenger response (10), CHO cell clones transfected with the different mutant V2 receptor constructs were screened initially by immunological techniques based on the detection of the aminoterminal HA-tag. First, we attempted to screen stable cell lines by using a previously developed indirect cellular ELISA system (9). Unfortunately, none of the cell clones showed any de-

Table II. Functional Activity of Various G Protein-coupled Receptors Coexpressed with the V2-Tail Fragment

\begin{tabular}{|c|c|c|c|c|}
\hline \multirow[b]{2}{*}{ Transfected construct(s) } & \multicolumn{2}{|l|}{ IP } & \multicolumn{2}{|l|}{ cAMP } \\
\hline & Maximum increase in IP levels & Agonist $\mathrm{EC}_{50}$ & Maximum increase in cAMP levels & Agonist $\mathrm{EC}_{50}$ \\
\hline & -Fold above basal & $n M$ & -Fold above basal & $n M$ \\
\hline V1a-R & 4.1 & $0.46 \pm 0.11$ & —* & - \\
\hline V1a-R/V2-tail & 5.2 & $0.76 \pm 0.09$ & - & - \\
\hline Ox-R & 2.9 & $3.6 \pm 0.1$ & - & - \\
\hline Ox-R/V2-tail & 2.3 & $3.1 \pm 0.4$ & - & - \\
\hline GnRH-R & 4.4 & $3.1 \pm 0.1$ & - & - \\
\hline GnRH-R/V2-tail & 5.1 & $3.9 \pm 0.7$ & - & - \\
\hline $\mathrm{CCK}_{\mathrm{A}}-\mathrm{R}$ & 4.6 & $3.7 \pm 1.6$ & - & - \\
\hline $\mathrm{CCK}_{\mathrm{A}}-\mathrm{R} / \mathrm{V} 2$-tail & 3.6 & $3.9 \pm 0.3$ & - & - \\
\hline LH-R & 1.8 & n.d. & 5.8 & $0.25 \pm 0.02$ \\
\hline LH-R/V2-tail & 2.0 & n.d. & 4.8 & $0.09 \pm 0.01$ \\
\hline
\end{tabular}

COS-7 cells were cotransfected with V2-tail ( $2 \mu \mathrm{g}$ plasmid DNA/dish) or vector DNA ( $2 \mu \mathrm{g}$ pcD-PS/dish as control, to keep the amount of DNA constant at $4 \mu \mathrm{g} / \mathrm{dish}$ ) and different $\mathrm{G}$ protein-coupled receptors ( $2 \mu \mathrm{g}$ plasmid DNA/dish; $R$, receptor). Functional assays were carried out as described in Methods. Transfected cells were stimulated with the appropriate agonists (AVP, Ox, GnRH, sulfated CCK 8, and human chorionic gonadotropin, respectively). $\mathrm{EC}_{50}$ and $\mathrm{E}_{\max }$ values were obtained from agonist concentration-response curves, using the computer program GraphPad Prism. Data are given as means \pm SEM of two or three independent experiments, each carried out in duplicate. n.d., not determinable with sufficient accuracy. IP, inositol phosphate. *No significant increase in cAMP above basal levels. 
Table III. Functional Characterization of CHO Cell Lines Stably Expressing Wild-Type or Mutant V2 Receptors after Infection with Ad-V2-Tail

\begin{tabular}{|c|c|c|c|}
\hline \multirow[b]{2}{*}{ Cell clones } & \multirow{2}{*}{$\frac{\text { AVP binding }}{\mathrm{B}_{\max }}$} & \multicolumn{2}{|l|}{ cAMP } \\
\hline & & $\begin{array}{l}\text { Maximum increase } \\
\text { in cAMP levels }\end{array}$ & $\mathrm{AVP} \mathrm{EC}_{50}$ \\
\hline & fmol/mg protein & -Fold above basal & $p M$ \\
\hline V2-1 & $21.4 \pm 2.6$ & 15.4 & $74 \pm 20$ \\
\hline V2-1 + Ad-V2-tail & n.d. & 17.5 & $136 \pm 30$ \\
\hline V2-1 + Ad- $\beta$ Gal & n.d. & 13.2 & $85 \pm 7.6$ \\
\hline V2-2 & - & 5.6 & $164 \pm 29$ \\
\hline E242stop + Ad- $\beta$ Gal & - & - & - \\
\hline E242stop + Ad-V2-tail & - & 3.9 & $133 \pm 16$ \\
\hline $\mathrm{Y} 280 \mathrm{C}+\mathrm{Ad}-\beta \mathrm{Gal}$ & - & - & - \\
\hline Y280C + Ad-V2-tail & - & 3.4 & $97 \pm 22$ \\
\hline W284stop + Ad- $\beta$ Gal & - & - & - \\
\hline W284stop + Ad-V2-tail & - & 4.7 & $129 \pm 12$ \\
\hline
\end{tabular}

Stable $\mathrm{CHO}$ cell lines expressing wild-type or mutant V2 receptors were tested in radioligand-binding and cAMP assays as described in Methods. $\mathrm{CHO}$ clones expressing mutant V2 receptors did not show any specific radioligand-binding activity or increases in cAMP production after stimulation with $100 \mathrm{nM}$ AVP. CHO cells were infected with Ad-V2-tail $(1,000 \mathrm{pfu} / \mathrm{cell})$ and assayed $3 \mathrm{~d}$ after infection. Data are given as means \pm SEM of two (binding assay) or three (cAMP assay) independent experiments, each carried out in duplicate. n.d., not determined.

tectable cell-surface expression (detection limit of the ELISA system $=40 \mathrm{fmol} / \mathrm{mg}$ protein; data not shown). We next tried to determine receptor levels in stable cell lines from total cell extracts by sandwich ELISA. Since many mutant receptor proteins are retained in the cell interior (29), this ELISA was expected to be more sensitive than a cell-surface ELISA. Consistent with this notion, the sandwich ELISA was able to detect receptor levels as low as $10 \mathrm{fmol} / \mathrm{mg}$ protein (Fig. 3 B). However, it should be noted that only full-length V2 receptor constructs in which both epitopes are present can be detected by sandwich ELISA. Lysates from the CHO clones V2-1 and Y280C gave OD values corresponding to $B_{\max }$ values of $\sim 14$ and $9 \mathrm{fmol} / \mathrm{mg}$, respectively.

To detect expression of mutant V2 receptor mRNA in the various G418-resistant cell lines, RT-PCR analysis was used (Fig. 4 A). Primers were chosen so that the sizes of amplified PCR products would be characteristic for individual receptors. V2 receptor mRNA was found in all cell lines investigated, and PCR products obtained with the truncated V2 receptors were distinguishable by their smaller size (406 bp for E242stop and $532 \mathrm{bp}$ for W284stop). To be able to compare receptor mRNA levels in different CHO cell lines, a competitive PCR strategy was used (28). cDNAs resulting from RT were coamplified with a standard dilution series of a plasmid containing genomic V2 receptor sequence (genomic V2-pcD-PS). Primers were chosen to flank a small 106-bp intron (present at amino acid codon 304) in the V2 receptor gene. To ensure accurate amplification of cDNA species, we first performed competitive PCR on known amounts of mutant V2-Y280C plasmid DNA. It can be seen in Fig. $4 B$ that the intensity of the resultant Y280C PCR product (638 bp) decreased in the presence of increasing amounts of competitor DNA. In lanes where the two PCR products show similar intensity, standard DNA and probe DNA are thought to be present at similar copy numbers. Since the number of cells used for mRNA preparation and the absolute amount of added standard DNA are known, the number of mRNA molecules present in a single cell can be estimated. This method somewhat underestimates absolute mRNA levels, because mRNA preparation and RT reaction are usually not quantitative. Using identical cell numbers from stably transfected $\mathrm{CHO}$ cell lines for mRNA preparation, and assuming similar efficiencies of the RT reactions, this method should allow a reasonable comparison of relative receptor mRNA levels present in the different $\mathrm{CHO}$ cell clones. Thus, V2-1, E242stop, W284stop, and Y280C cell clones were found to express similar levels of V2 (wild-type or mutant) mRNA ( 200-300 molecules/cell; $n=2-3$ ). As expected from functional and radioligand-binding assays, mRNA levels in clone V2-2 were estimated to be significantly lower ( $\sim 70$ molecules/ cell).

Functional rescue of mutant $V 2$ receptors by adenovirusmediated gene transfer. We next wanted to examine whether the various $\mathrm{CHO}$ cell lines expressing low amounts of mutant V2 receptors would gain the ability to mediate AVP-dependent increases in cAMP levels in the presence of the V2-tail

A

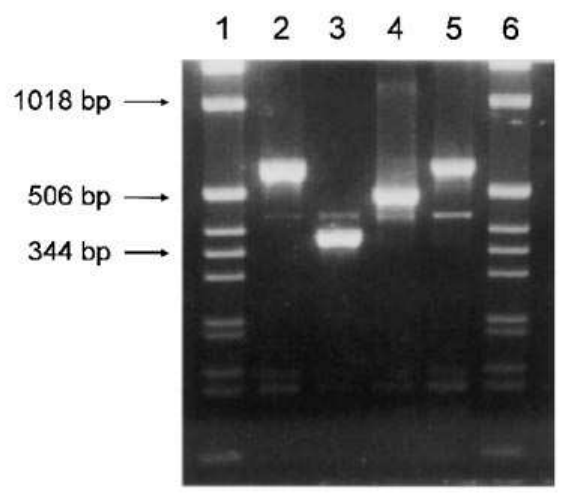

B

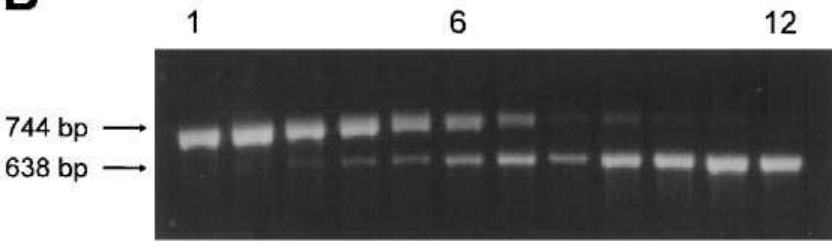

Figure 4. PCR-based analysis of mRNA expression in CHO cells stably transfected with mutant vasopressin receptors. $(A)$ RT-PCR analysis was performed using mRNA isolated from $\mathrm{CHO}$ cell lines stably expressing wild-type and mutant $\mathrm{V} 2$ vasopressin receptors as described in Methods. A pair of V2 receptor-specific primers was used (see Methods). PCR products were separated on a $1.5 \%$ agarose gel and stained with ethidium bromide (lanes 1 and $6: 1-\mathrm{kb}$ standard). The following cell clones were analyzed: V2-2 (lane 2), E242stop (lane 3), W284stop (lane 4), and Y280C (lane 5). (B) PCR reactions were carried out with a constant amount of Y280C cDNA $\left(3 \times 10^{7}\right.$ molecules) in the presence of varying amounts of genomic V2pcD-PS as a competing DNA template. Lanes 1-12 correspond to geometric dilutions of genomic V2-pcD-PS, starting at $2 \times 10^{9}$ molecules. 

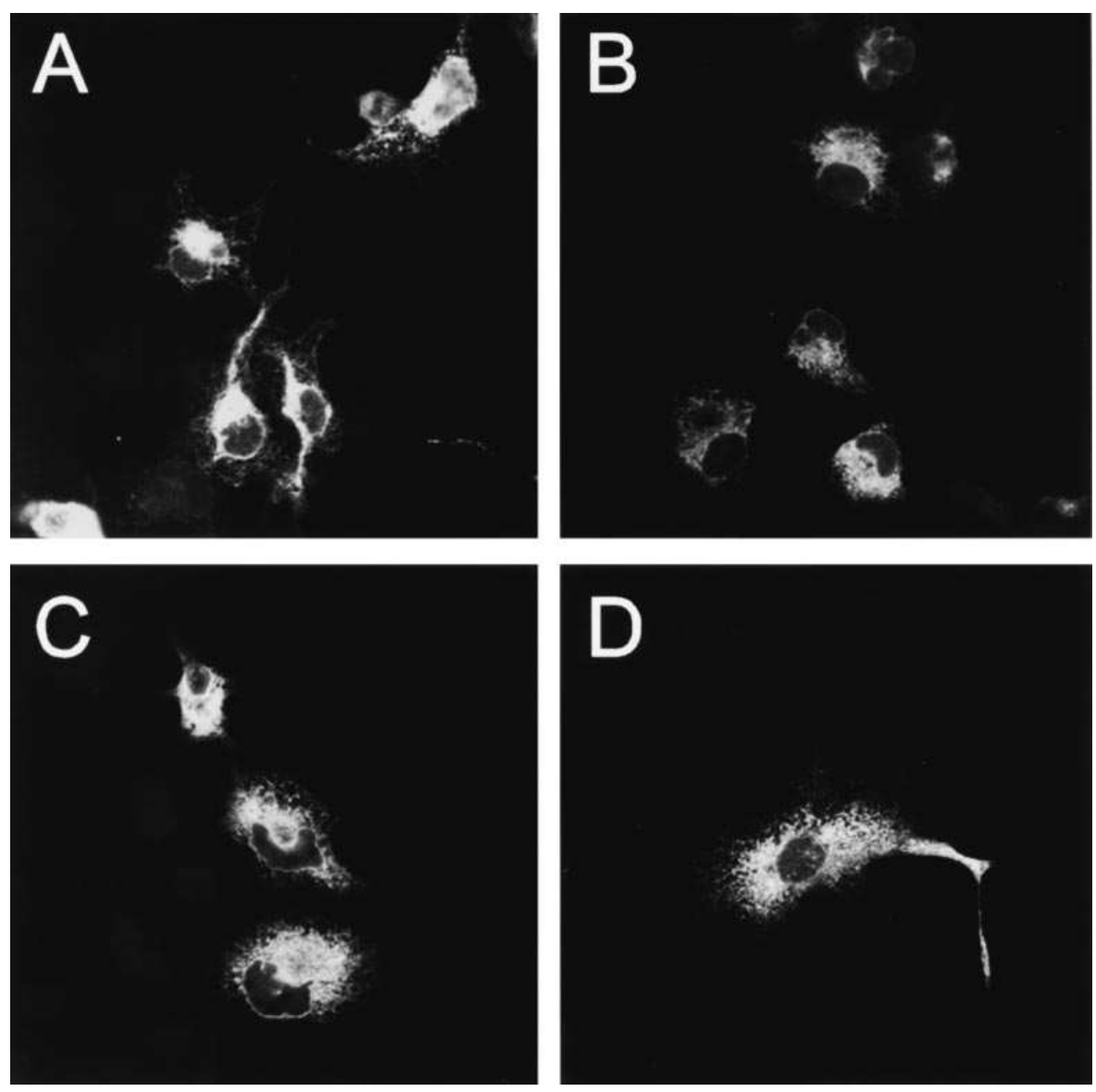

Figure 5. Expression of wild-type V2 receptor and V2-tail polypeptide in COS-7 and MDCK cells after adenovirus-mediated gene transfer. COS-7 ( $A$ and $B$ ) and MDCK cells $(C$ and $D)$ were infected with Ad-V2 ( $A$ and $C$ ) and Ad-V2-tail ( $B$ and $D)(100 \mathrm{pfu} / \mathrm{cell})$, respectively. Immunofluorescence studies were carried out with permeabilized cells grown on glass coverslips, as described in Methods. Cells were treated with a rabbit polyclonal antibody directed against the carboxy-terminus of the human V2 receptor and then incubated with an FITC-linked goat anti-rabbit IgG secondary antibody. Fluorescence images were obtained with a confocal laser scanning microscope. Each picture is representative of at least two independent experiments.

polypeptide. Given the potential therapeutic importance of these rescue experiments, the V2-tail gene fragment was delivered to the various $\mathrm{CHO}$ cell lines using a recombinant adenovirus. To generate recombinant adenovirus vectors, we used a strategy based on plasmid pJM17, which contains all essential adenovirus sequences required to produce infectious virus upon transfection of HEK 293 cells (21). The resulting viruses (Ad-V2 and Ad-V2-tail) carried the foreign expression cassette inserted into the $\mathrm{E} 1$ region (Fig. $1 C$ ).

To test the efficacy of adenovirus-mediated gene transfer, we first infected COS-7 cells with Ad-V2. 3 d after infection (25 pfu/cell), cells showed an eightfold AVP-induced (100 nM) increase in intracellular cAMP levels. Additionally, COS-7 cells that had been transiently transfected with the E242stop mutant receptor were infected with Ad-V2-tail ( $25 \mathrm{pfu} / \mathrm{cell}) .3 \mathrm{~d}$ after infection, these cells, when incubated with $100 \mathrm{nM} \mathrm{AVP}$, showed a threefold increase in cAMP levels. Moreover, adenovirus-mediated gene transfer was also verified by immunocytochemical techniques. As shown in Fig. 5, $A$ and $B$, COS-7 cells infected with Ad-V2 or Ad-V2-tail showed an intense staining of cellular membranes when probed with an anti-V2 vasopressin receptor antibody.

Based on these results, the various $\mathrm{CHO}$ cell lines stably expressing low levels of mutant V2 receptors (E242stop, Y280C, and W284stop) were incubated with increasing amounts of Ad-V2-tail virus (Fig. 6 A). After infection with Ad-V2-tail and stimulation with AVP, these $\mathrm{CHO}$ cell lines gained the ability to mediate 3.4-4.7-fold increases in intracellular cAMP levels (Table III, Fig. 6 B). These responses were characterized by remarkably high AVP potencies $\left(\mathrm{EC}_{50}=97-\right.$ 133 pM; wild-type V2 receptor $\mathrm{EC}_{50}=74-164 \mathrm{pM}$ ). However, in order to observe these responses, relatively high virus concentrations had to be applied. Using an Ad-V2-tail virus concentration of 1,000 pfu/cell (the maximal titer of our purified virus stock was $\left.5 \times 10^{10} \mathrm{pfu} / \mathrm{ml}\right)$, AVP-induced maximum cAMP responses still showed a sharp increase, indicating that the virus concentration was the limiting factor in the efficacy of functional rescue (Fig. $6 \mathrm{~A}$ ). To further address the question, we determined infection efficiencies by incubating nontransfected $\mathrm{CHO}$ cells with an adenovirus carrying the $\beta$-galactosidase gene (1,000 pfu Ad- $\beta$ Gal/cell). 3 d after infection, only $27 \%$ of the total cell population showed positive nuclear staining after incubation with X-Gal. Stepwise dilution of Ad- $\beta$ Gal (300 and $100 \mathrm{pfu} / \mathrm{cell}$ ) further reduced the percentage of infected cells to 13 and $4 \%$, respectively. This result indicated that adenovirus-mediated gene transfer is considerably less efficient in $\mathrm{CHO}$ than in COS-7 cells, where $93 \%$ of all cells can be infected when $300 \mathrm{pfu} / \mathrm{cell}$ of Ad- $\beta \mathrm{Gal}$ is applied. Additionally, we used competitive RT-PCR to determine V2-tail mRNA levels in $\mathrm{CHO}$ cells $3 \mathrm{~d}$ after infection with Ad-V2-tail $(1,000 \mathrm{pfu} / \mathrm{cell})$. These experiments suggested that $\sim 100 \mathrm{~V} 2-$ tail mRNA molecules are present per cell. Therefore, given an infection efficiency of $\sim 30 \%$ (see above), 300-400 mRNA molecules appear to be present per infected $\mathrm{CHO}$ cell.

In a set of control experiments, we infected CHO-V2-1 cell line with Ad-V2-tail or Ad- $\beta$ Gal. The maximal cAMP response to AVP administration and the $\mathrm{EC}_{50}$ values were unchanged, indicating that adenoviral infection itself had no sig- 
A

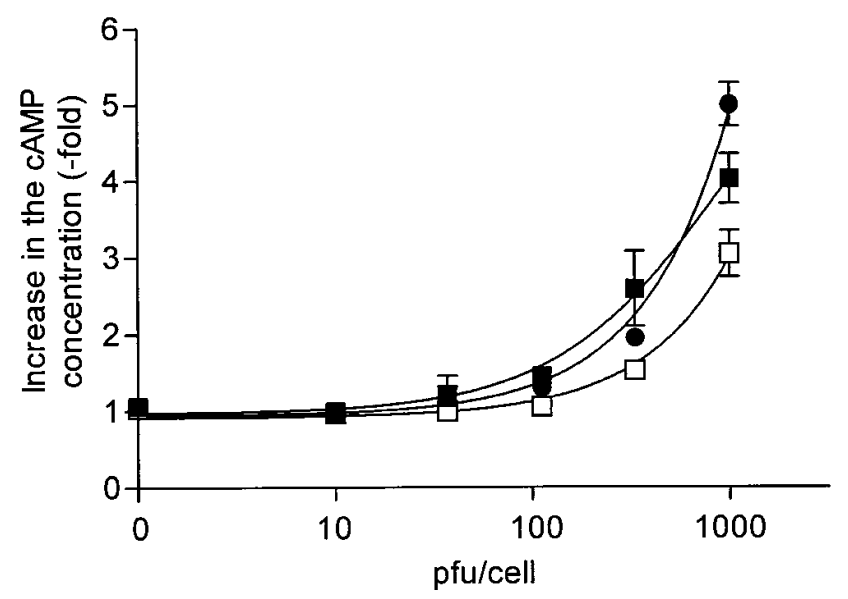

B

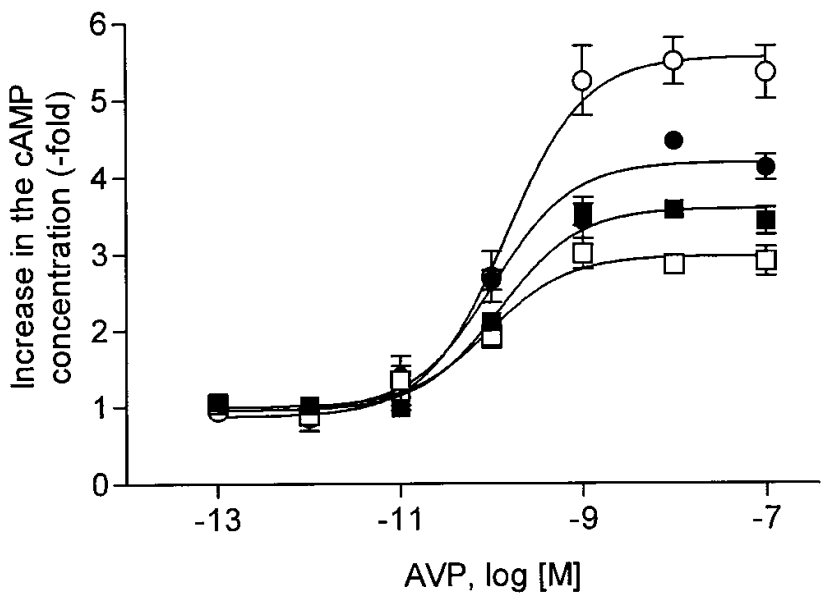

Figure 6. Functional rescue of mutant V2 receptors stably expressed in $\mathrm{CHO}$ cells by adenovirus-mediated gene transfer. $(A) \mathrm{CHO}$ cell lines stably expressing different V2 mutant receptors were infected with various amounts of Ad-V2-tail virus, and AVP-induced (100 $\mathrm{nM}$ ) increases in cAMP levels were determined as described in Methods. Responses are expressed as fold increase in cAMP content above basal levels $(122 \pm 15 \mathrm{cpm})$ determined in the absence of AVP. (B) To estimate $\mathrm{EC}_{50}$ values, the different $\mathrm{CHO}$ cell lines were infected with $1,000 \mathrm{pfu} / \mathrm{cell}$ of Ad-V2-tail virus and incubated with increasing concentrations of AVP. Data are presented as means \pm SEM of two independent experiments, each carried out in duplicate. Cell clone V2-2

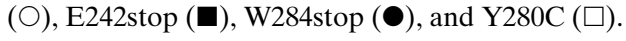

nificant effect on V2 receptor function (see Table III). On the other hand, infection of $\mathrm{CHO}$ cell lines expressing the different mutant $\mathrm{V} 2$ receptors with Ad- $\beta \mathrm{Gal}$ did not result in a gain in receptor function (see Table III).

Adenovirus-mediated gene transfer into a renal tubular cell line. We next wanted to demonstrate that the two recombinant adenovirus vectors, Ad-V2 and Ad-V2-tail, can also be used to infect renal tubular cells. For these experiments, the dog renal tubular cell line (MDCK) was used. Immunocytochemical studies proved to be too insensitive to detect the presence of endogenous V2 vasopressin receptor protein in this cell line (data not shown). However, a weak but highly reproducible increase in cAMP levels (1.5-fold over basal) was demonstrated after administration of $100 \mathrm{nM}$ AVP, suggesting the presence of very low levels of endogenous V2 receptors. After these initial experiments, MDCK cells were infected with Ad-V2 (100 pfu/cell), and cAMP assays were performed $3 \mathrm{~d}$ later. We found that incubation of infected cells with $100 \mathrm{nM}$ AVP resulted in a 9.4-fold increase in cAMP levels. Consistent with this result, studies with the recombinant Ad- $\beta$ Gal virus (300 pfu/cell) indicated that MDCK cells can be infected with rather high efficiency $(\sim 75 \%)$. In addition, immunocytochemical studies showed intense staining of cellular membranes in MDCK cells infected with the Ad-V2 or Ad-V2-tail virus (Fig. 5, $C$ and $D$ ); however, fluorescence signals were slightly weaker than those seen in COS-7 cells.

\section{Discussion}

Inactivating mutations in distinct GPCRs have been identified as the cause of an ever-growing number of human diseases (6). For example, numerous mutations (which include missense, nonsense, deletion, or frameshift mutations) have been found in the human V2 vasopressin receptor that are responsible for the X-linked form of NDI. As a result, the encoded mutant receptors are impaired in their ability to bind ligands and/or to couple to $G$ proteins; in addition, it has been shown that many of these mutant receptors are not properly trafficked to the cell surface (29). From a therapeutic point of view, it would be highly desirable to devise strategies that can restore function to mutationally inactivated GPCRs. Based on the previous observation that GPCRs are assembled from multiple autonomous folding domains $(8,9)$, we speculated that it might be possible to functionally rescue mutant GPCRs by supplying the receptor fragment that is misfolded or lacking in the mutant receptor(s). Indeed, we demonstrated recently in transiently transfected COS-7 cells that selected mutant V2 receptors containing mutations in the carboxy-terminal third of the receptor protein regained considerable functional activity when coexpressed with a V2-tail spanning the region where the various mutations occurred (10).

One important goal of this study was to investigate by which molecular mechanism the coexpressed V2-tail polypeptide can restore function to mutationally inactivated V2 receptors. Since we could rule out the possibility of homologous recombination at the plasmid level, as seen in the immunoprecipitation studies (see Fig. 2) and using a V2-tail construct lacking the initiating ATG translation start codon (10), we considered it likely that the V2-tail fragment directly associates with the mutant $\mathrm{V} 2$ receptor(s); however, direct evidence was lacking. To test this hypothesis, two different experimental strategies, a sandwich ELISA and a coimmunoprecipitation protocol, were used. Using the E242stop mutant V2 receptor as a model system, we could indeed demonstrate a direct interaction of the V2-tail polypeptide with the mutant V2 receptor. Treatment with SDS or heating of cell lysates to $80^{\circ} \mathrm{C}$ resulted in the dissociation of the E242stop-V2-tail complex, indicating that complex formation is driven by noncovalent interactions, most likely by helix-helix packing. It is possible that molecular chaperones that are likely to assist folding of the wild-type receptor proteins may also play a role in facilitating complex (E242stop-V2-tail) formation. Consistent with this notion, we have been unable to assemble functional V2 receptor proteins 
from solubilized receptor fragments in vitro. Interestingly, it has been shown recently that chaperone-dependent mechanisms are essential for proper folding of rhodopsin and most likely other GPCRs $(30,31)$. However, the identity of the chaperones required for the proper folding of GPCRs that are different from rhodopsin remains to be elucidated.

Sandwich ELISA studies also showed that introduction of various mutations (Y280C, L292P, and V277del, all located in the sixth transmembrane helix) into the V2-tail polypeptide did not interfere with the ability of the polypeptide to form a complex with the E242stop V2 mutant receptor, indicating that these mutations do not exert a very dramatic effect on receptor assembly. Since the full-length V2 receptors containing these mutations can no longer bind ligands and couple to $G$ proteins (10), it appears likely that these point mutations (Y280C, L292P) and the triplet deletion (V277del) in the sixth transmembrane helix result in minor conformational changes, causing the functional inactivation of the mutant $\mathrm{V} 2$ receptor protein. The observed ability of the V2-tail fragment to interact with different mutant V2 receptors is consistent with several recent reports suggesting that GPCRs can form dimers. Using chimeric $\alpha_{2}$-adrenergic/m3 muscarinic receptors, Maggio et al. (32) demonstrated that chimeric receptors can complement each other functionally. Also, receptor dimerization can explain the reconstitution of binding activity after coexpression of two binding-defective point mutants of the angiotensin II type 1 receptor (33). Finally, Bouvier and co-workers (34) recently used a double epitope tagging approach to directly demonstrate dimer formation of the $\beta_{2}$-adrenergic receptor in transiently and stably transfected cells.

By taking advantage of sandwich ELISA and the ability of complementary V2 receptor fragments to form functional receptor complexes, it should be possible to screen a large number of V2 receptor mutations for their ability to interfere with proper receptor assembly. Such studies are likely to lead to the identification of critical interhelical contact sites, and may therefore provide novel insights into the molecular architecture of the transmembrane core of GPCRs.

To verify that the V2-tail fragment does not interfere with the function of other GPCRs, the V2-tail polypeptide was coexpressed in COS-7 cells with wild-type V1a vasopressin, Ox, $\mathrm{GnRH}, \mathrm{CCK}_{\mathrm{A}}$, and $\mathrm{LH}$ receptors. We found that the coexpressed V2-tail polypeptide had no significant effect on the functional responses mediated by the different wild-type receptors and was unable to form complexes with truncated $\mathrm{m} 3$ muscarinic or GnRH receptors. This observation suggests that the interaction of the V2-tail fragment with mutant V2 receptors is characterized by a very high degree of specificity. Based on this finding, it is likely that delivery of the V2-tail polypeptide (or analogous peptides derived from other GPCRs) to the kidney will lead to functional effects only in those cells where the V2 receptor is physiologically expressed. In contrast, improper targeting of a viral vector encoding the wild-type V2 receptor might result in serious side effects, particularly since AVP can reach virtually every body cell via the blood stream.

Since transfection of COS-7 cells is known to lead to very high levels of protein expression in only a small subset of cells with receptor densities estimated to be 10-100 times higher than those found in native tissues, another major goal of this study was to show that this coexpression approach can also be successfully applied when the mutant receptors are expressed at rather low (physiological) levels. Towards this aim, we es- tablished $\mathrm{CHO}$ cell lines stably expressing low levels of three different mutant V2 vasopressin receptors, E242stop, Y280C, and W284stop. Gene transfer methods used in cell culture are usually inefficient or impractical in vivo. However, recombinant adenoviruses have been used successfully to introduce foreign genes into a great variety of physiological tissues and cell types, including cultured renal cells (35) and renal tubular cells in vivo (36). Therefore, given the potential therapeutic usefulness of the described coexpression strategy, we constructed two replication-deficient recombinant adenoviruses coding for the wild-type V2 receptor and the V2-tail polypeptide, resulting in Ad-V2 and Ad-V2-tail, respectively. Whereas none of the $\mathrm{CHO}$ cell lines expressing low levels of mutant V2 receptors (E242stop, Y280C, or W284stop) was able to mediate a significant increase in intracellular cAMP levels upon incubation with AVP, a pronounced cAMP response was restored after infection with the Ad-V2-tail virus. The observed AVP concentration-response curves were characterized by $\mathrm{EC}_{50}$ values very similar to the corresponding wild-type receptor values (70-160 pM). However, maximal cAMP responses were approximately fourfold reduced compared to a $\mathrm{CHO}$ cell line expressing the wild-type $\mathrm{V} 2$ receptor at similar levels (judged by estimating receptor mRNA levels). One possible reason for the reduced degree of functional rescue seen in CHO compared to COS-7 cells (10) could be that the Ad-V2tail virus infected only a subpopulation of the mutant receptor-expressing $\mathrm{CHO}$ cells, whereas the wild-type $\mathrm{V} 2$ receptor is present in all cells of the stable $\mathrm{CHO}$ cell line studied. To test this hypothesis, we examined the ability of $\mathrm{CHO}$ cells to be infected by Ad- $\beta$ Gal, a recombinant adenovirus vector coding for bacterial $\beta$-galactosidase. Surprisingly, these studies showed that adenoviral infection of fibroblast-like $\mathrm{CHO}$ cells was much less efficient ( $<30 \%$ using 1,000 pfu Ad- $\beta \mathrm{Gal} / \mathrm{cell}$ ) than previously reported for rodent epithelium cells $(11,33)$ or found with monkey (COS-7) or dog (MDCK) renal epithelial cells. Therefore, given the fact that the Ad-V2-tail virus is likely to infect $<30 \%$ of $\mathrm{CHO}$ cells expressing mutant V2 receptors, the observed degree of functional rescue appears quite remarkable. Another important point was to demonstrate that the Ad-V2-tail and Ad-V2 viruses can also infect renal epithelial cells where the V2 vasopressin receptor is physiologically expressed. For these experiments, the dog renal tubular cell line, MDCK, was used. We showed that MDCK cells could be infected efficiently by the Ad-V2-tail and Ad-V2 viruses. The two viruses directed the expression of high levels of V2 receptor protein and the V2-tail fragment, as shown by immunocytochemical techniques. Both polypeptides showed a similar subcellular distribution, characterized by the staining of intracellular membranes (endoplasmic reticulum-Golgi complex) and the plasma membrane. In addition, MDCK cells infected with Ad-V2 showed a dramatic increase in intracellular cAMP levels after the addition of AVP.

The findings described here may be relevant not only for other members of the GPCR family but also for polytopic integral membrane proteins in general. It has been demonstrated for example, that many proteins that contain multiple membrane-spanning domains can be assembled from two or more protein fragments. These proteins include sodium channels (37), the a-factor transporter in yeast (38), adenylyl cyclases (39), and lactose permease $(40,41)$. Based on the subunit character of integral membrane proteins, the rescue strategy described here for mutant $\mathrm{V} 2$ vasopressin receptors may also be 
applicable to other classes of (mutant) membrane proteins that may play a role in human disease.

In conclusion, using mutant $\mathrm{V} 2$ vasopressin receptors as a model system, we demonstrated that mutationally inactivated GPCRs can be functionally rescued via adenovirus-mediated gene transfer of a carboxy-terminal receptor fragment. Based on the efficiency and specificity of the observed rescue phenomenon, the application of this approach for gene therapy purposes appears promising. Therefore, it should be of considerable interest to study the feasibility of this novel therapeutic strategy in a transgenic animal model.

\section{Acknowledgments}

We would like to thank Dr. B. Wiedenmann, Universitätsklinikum Benjamin Franklin, Freie Universität Berlin, for access to a confocal laser scanning microscope. The cDNAs of V1a vasopressin and Ox receptors were generous gifts of Dr. M.J. Brownstein, National Institutes of Health. We are thankful to Dr. S.A. Wank, National Institutes of Health, for donating the CCK type A and B receptors, and Dr. P. Goldsmith, also of the National Institutes of Health, for supplying an affinity-purified polyclonal antibody raised against the carboxy terminus of the human V2 vasopressin receptor.

This work was supported by the Deutsche Forschungsgemeinschaft and Fonds der Chemischen Industrie.

\section{References}

1. Strader, C.D., T.M. Fong, M.R. Tota, D. Underwood, and R.A.F. Dixon. 1994. Structure and function of $\mathrm{G}$ protein-coupled receptors. Annu. Rev. Biochem. 63:101-132.

2. Sung, C.H., B.G. Schneider, N. Agarwal, D.S. Papermaster, and J. Nathans. 1991. Functional heterogeneity of mutant rhodopsins responsible for autosomal dominant retinitis pigmentosa. Proc. Natl. Acad. Sci. USA. 88:88408844.

3. Shenker, A., L. Laue, S. Kosugi, J.J. Merendino, T. Minegishi, and G.B. Cutler, Jr. 1993. A constitutively activating mutation of the luteinizing hormone receptor in familial male precocious puberty. Nature (Lond.). 365:652-654

4. Parma, J., L. Duprez, J. van Sande, P. Cochaux, C. Gervy, J. Mockel, J. Dumont, and G. Vassart. 1993. Somatic mutations in the thyrotropin receptor gene cause hyperfunctioning thyroid adenomas. Nature (Lond.). 365:649-651.

5. Rosenthal, W., A. Seibold, A. Antaramian, M. Lonergan, M.F. Arthus, G.N. Hendy, M. Birnbaumer, and D.G. Bichet. 1992. Molecular identification of the gene responsible for congenital nephrogenic diabetes insipidus. Nature (Lond.). 359:233-235.

6. Spiegel, A.M. 1996. Defects in G protein-coupled signal transduction in human disease. Annu. Rev. Physiol. 58:143-170.

7. Wildin, R.S., M.J. Antush, R.L. Bennett, J.M. Schoof, and C.R. Scott. 1994. Heterogeneous AVPR2 gene mutations in congenital nephrogenic diabetes insipidus. Am. J. Hum. Genet. 55:266-277.

8. Ridge, K.D., S.S.J. Lee, and L.L. Yao. 1995. In vivo assembly of rhodopsin from expressed polypeptide fragments. Proc. Natl. Acad. Sci. USA. 92:32043208.

9. Schöneberg, T., J. Liu, and J. Wess. 1995. Plasma membrane localization and functional rescue of truncated forms of a $\mathrm{G}$ protein-coupled receptor. $J$. Biol. Chem. 270:18000-18006.

10. Schöneberg, T., J. Yun, D. Wenkert, and J. Wess. 1996. Functional rescue of mutant V2 vasopressin receptors causing nephrogenic diabetes insipidus by a co-expressed receptor polypeptide. EMBO (Eur. Mol. Biol. Organ.) J. 15: 1283-1291.

11. Rosenfeld, M.A., W. Siegfried, K. Yoshimura, K. Yoneyama, M. Fukayama, L.E. Stier, P.K. Paakko, P. Gilardi, L.D. Stratford-Perricaudet, M. Perricaudet, et al. 1991. Adenovirus-mediated transfer of a recombinant $\alpha 1$ antitrypsin gene to the lung epithelium in vivo. Science (Wash. DC). 252:431-434.

12. Rosenfeld, M.A., K. Yoshimura, B.C. Trapnell, K. Yoneyama, E.R. Rosenthal, W. Dalemans, M. Fukayama, J. Bargon, L.E. Stier, L.D. StratfordPerricaudet, et al. 1992. In vivo transfer of the human cystic fibrosis transmembrane conductance regulator gene to the airway epithelium. Cell. 68:143-155.

13. Higuchi, R. 1989. Using PCR to engineer DNA. In PCR Technology. H.A. Ehrlich, editor. Stockton Press, New York. 61-70.

14. Morel, A., A.-M. O'Carroll, M.J. Brownstein, and S.J. Lolait. 1992. Molecular cloning and expression of a rat V1a vasopressin receptor. Nature (Lond.). 356:523-526.

15. Kimura, T., O. Tanizawa, K. Mori, M.J. Brownstein, and H. Okayama.
1992. Structure and expression of a human oxytocin receptor. Nature (Lond.). 356:526-529.

16. Wank, S.A., R. Harkins, R.T. Jensen, H. Shapira, A. de-Weerth, and T. Slattery. 1992. Purification, molecular cloning, and functional expression of the cholecystokinin receptor from rat pancreas. Proc. Natl. Acad. Sci. USA. 89: $3125-3129$.

17. Gudermann, T., M. Birnbaumer, and L. Birnbaumer. 1992. Evidence for dual coupling of the murine luteinizing hormone receptor to adenylyl cyclase and phosphoinositide breakdown and $\mathrm{Ca}^{2+}$ mobilization. J. Biol. Chem. 267: 4479-4488.

18. Kolodziej, P.A., and R.A. Young. 1991. Epitope tagging and protein surveillance. Methods Enzymol. 194:508-519.

19. Sanger, F., S. Nicklen, and A.R. Coulson. 1977. DNA sequencing with chain-terminating inhibitors. Proc. Natl. Acad. Sci. USA. 91:5463-5467.

20. Bett, A.J., W. Haddara, L. Prevec, and F.L. Graham. 1994. An efficient and flexible system for construction of adenovirus vectors with insertions or deletions in early regions 1 and 3. Proc. Natl. Acad. Sci. USA. 91:8802-8806.

21. McGrory, W.J., D.S. Bautista, and F.L. Graham. 1988. A simple technique for the rescue of early region I mutations into infectious human adenovirus type 5. Virology. 163:614-617.

22. Lieber, A., V. Sandig, and M.A. Strauss. 1993. A mutant T7 phage promoter is specifically transcribed by T7-RNA polymerase in mammalian cells. Eur. J. Biochem. 217:387-394.

23. Kanegae, Y., M. Makimura, and I. Saito. 1994. A simple and efficient method for purification of infectious recombinant adenovirus. Jpn. J. Med. Sci. Biol. 47:157-166.

24. Cullen, B.R. 1987. Use of eucaryotic expression technology in the functional analysis of cloned genes. Methods Enzymol. 152:684-704.

25. Stratford-Perricaudet, L.D., I. Makeh, M. Perricaudet, and P. Briand. 1992. Widespread long-term gene transfer to mouse skeletal muscles and heart. J. Clin. Invest. 90:626-630.

26. Bradford, M.M. 1976. A rapid and sensitive method for the quantitation of microgram quantities of protein utilizing the principle of protein dye binding. Anal. Biochem. 72:248-254.

27. Munson, P.J., and D. Rodbard. 1980. LIGAND: a versatile computerized approach for characterization of ligand-binding systems. Anal. Biochem. 107:220-239.

28. Siebert, P.D., and J.W. Larrick. 1992. Competitive PCR. Nature (Lond.). 359:557-558.

29. Wenkert, D., T. Schöneberg, J.J. Merendino, M.S.R. Pena, R. Vinitsky, P.K. Goldsmith, J. Wess, and A.M. Spiegel. 1996. Functional characterization of five V2 vasopressin receptor gene mutations. Mol. Cell. Endocrinol. 124:4350 .

30. Baker, E.K., N.J. Colley, and C.S. Zuker. 1994. The cyclophilin homolog NinaA functions as a chaperone, forming a stable complex in vivo with its protein target rhodopsin. EMBO (Eur. Mol. Biol. Organ.) J. 13:4886-4896.

31. Ferreira, P.A., T.A. Nakayama, W.L. Pak, and G.H. Travis. 1996. Cyclophilin-related protein RanBP2 acts as a chaperone for red/green opsin. Nature (Lond.). 383:637-640.

32. Maggio, R., Z. Vogel, and J. Wess. 1993. Coexpression studies with mutant muscarinic/adrenergic receptors provide evidence for intermolecular crosstalk between G protein-linked receptors. Proc. Natl. Acad. Sci. USA. 90: 3103-3107.

33. Monnot, C., C. Bihoreau, C. Cinchon, K.M. Curnow, P. Corvol, and E. Clauser. 1996. Polar residues in the transmembrane domains of the type 1 angiotensin II receptor are required for binding and coupling. Reconstitution of the binding site by co-expression of two deficient mutants. J. Biol. Chem. 271: 1507-1513.

34. Hebert, T.E., S. Moffett, J.P. Morello, T.P. Loisel, D.G. Bichet, C. Barret, and M. Bouvier. 1996. A peptide derived from a $\beta_{2}$-adrenergic receptor transmembrane domain inhibits both receptor dimerization and activation. $J$. Biol. Chem. 271:16384-16392.

35. Chang, H., T. Katoh, M. Nodo, Y. Kanegae, I. Saito, S. Asano, and K. Kurokawa. 1995. Highly efficient adenovirus-mediated gene transfer into renal cells in culture. Kidney Int. 47:322-326.

36. Mollier, P., G. Friedlander, D. Calise, P. Ronco, M. Perricaudet, and N. Ferry. 1994. Adenoviral-mediated gene transfer to renal tubular cells in vivo. Kidney Int. 45:1220-1225.

37. Stühmer, W., F. Conti, H. Suzuki, X. Wang, M. Noda, N. Yahagi, H. Kubo, and S. Numa. 1989. Structural parts involved in activation and inactivation of the sodium channel. Nature (Lond.). 339:597-603.

38. Berkower, C., and S. Michaelis. 1991. Mutational analysis of the yeast a-factor transporter STE6, a member of the ATP binding cassette (ABC) protein superfamily. EMBO (Eur. Mol. Biol. Organ.) J. 10:3777-3785.

39. Tang, W.J., M. Stanzel, and A.G. Gilman. 1995. Truncation and alaninescanning mutants of type I adenylyl cyclase. Biochemistry. 34:14563-14572.

40. Bibi, E., and H.R. Kaback. 1990. In vivo expression of the lacY gene in two segments leads to functional lac permease. Proc. Natl. Acad. Sci. USA. 87: 4325-4329.

41. Zen, K.H., E. McKenna, E. Bibi, D. Hardy, and H.R. Kaback. 1994. Expression of lactose permease in contiguous fragments as a probe for membranespanning domains. Biochemistry. 33:8198-8206. 